\title{
PENGARUH SUBSTITUSI TEPUNG KEDELAI, TEPUNG BEKATUL DAN TEPUNG RUMPUT LAUT (GRACILARIA SP) TERHADAP DAYA TERIMA, ZAT BESI DAN VITAMIN B12 BROWNIES
}

\author{
Effect of Soybean, Rice Bran, and Seaweed Flour (Gracilaria sp) Substitution on \\ The Acceptibility, Iron and Vitamin B12 of Brownies \\ Rahmasuci Fibriafi $^{1^{*}}$, Rita Ismawati ${ }^{2}$ \\ ${ }^{1}$ Program Studi Ilmu Gizi, Fakultas Kesehatan Masyarakat, Universitas Airlangga, Surabaya \\ ${ }^{2}$ Prodi Gizi, Jurusan PKK, Fakultas Teknik, Universitas Negeri Surabaya \\ E-mail: fibriafi@gmail.com
}

\begin{abstract}
ABSTRAK
Tepung kedelai, tepung bekatul dan tepung rumput laut (Gracilaria sp) termasuk beberapa bahan makanan yang merupakan sumber zat besi dan vitamin B12 sehingga berpotensi menjadi bahan yang dapat dikembangkan menjadi produk brownies sebagai salah satu snack alternatif untuk Wanita Usia Subur (WUS) ovo vegetarian. Penelitian ini bertujuan untuk menganalisa pengaruh substitusi tepung kedelai, tepung bekatul dan tepung rumput laut (Gracilaria $s p)$ terhadap daya terima dan nilai zat besi serta vitamin B12. Penelitian eksperimental murni ini menggunakan desain Rancang Acak lengkap (RAL). Terdapat 4 formula (F0, F1, F2, F3) dan masing-masing diulang sebanyak enam kali. Analisis uji perbedaan daya terima menggunakan Friedman Test dan uji lanjut menggunakan Wilcoxon Ranks Test. Panelis tidak terlatih yaitu 25 pada WUS dengan pola makan ovo vegetarian. Tidak terdapat perbedaan yang signifikan pada warna, aroma dan tekstur antar formula brownies. Terdapat perbedaan $(\mathrm{p}<0,05)$ pada karakteristik rasa brownies dan hasil uji lanjut Wilcoxon Ranks Test menunjukkan adanya perbedaan rasa $(\mathrm{p}<0,05)$ pada formula kontrol dan formula substitusi. Berdasarkan hasil uji daya terima, formula brownies substitusi yang mendapat penilaian terbaik adalah formula substitusi F3 (tepung terigu 37,5 g, tepung kedelai 22,5 g, tepung bekatul $75 \mathrm{~g}$, dan tepung rumput laut (Gracilaria sp) $15 \mathrm{~g}$ ). Kandungan zat besi dan vitamin B12 pada formula substitusi F3 sebesar 3,6 mg dan 0,2 $\mu \mathrm{g}$ pada 100 gram formula dan telah memenuhi $10-15 \%$ kebutuhan WUS. Kesimpulan dalam penelitian ini adalah formula F3 merupakan formula dengan daya terima, kandungan zat besi dan vitamin B12 terbaik sehingga dapat dijadikan sebagai snack alternatif untuk WUS dengan pola makan ovo vegetarian.
\end{abstract}

Kata kunci: tepung kedelai, tepung bekatul, tepung rumput laut (Gracilaria sp)

\section{ABSTRACT}

Soybean, rice bran and seaweed flour (Gracilaria sp) are food sources of iron and vitamin B12 so it is potential to be used as an ingredient for alternative snack for childbearing age women with ovo vegetarian diet. This research intended to analyze effect of soybean, rice bran and seaweed flour (Gracliaria sp) substitution on the acceptability, iron and vitamin B12 content. This research was true experimental research with completely randomized design. There are 4 formulas with six times replications. Analysis of accessibility different used was Friedman. Friedman Test and Wilcoxon Ranks Test. The untrained panelists were 25 childbearing age women with ovo vegetarian diet. The difference test showed that there were no difference in colour, aroma and texture. There was a difference $(p<0.05)$ on flavour characteristic and Wilcoxon Ranks Test showed that there was a difference $(p<0 v 05)$ between control formula and substitution formula. Based on the result of acceptability, brownies substitution formula with the best score was F3 formula (flour $37.5 \mathrm{~g}$, soybean flour $22.5 \mathrm{~g}$, rice bran $75 \mathrm{~g}$, and seaweed flour (Gracilaria sp) $15 \mathrm{~g}$ ). The iron and vitamin B12 content of F3 formula were $3.6 \mathrm{mg}$ and $0.2 \mu \mathrm{g}$ respectively on 100 gram formula and fulfill 10-15\% of childbearing age women's requirement. Finally, the best formula which obtained from its acceptability, iron and vitamin $B 12$ content was F3 formula, so it could be an alternative snack for childbearing age women with ovo vegetarian diet.

Keywords: soybean flour, rice bran flour, seaweed (Gracilaria sp) flour

Rahmasuci Fibriafi, et al., MGI(2018) 12-19

DOI: 10.20473/mgi.v13i1.12-19. 


\section{PENDAHULUAN}

Saat ini pola makan vegetarian telah banyak menjadi pilihan masyarakat. Pelaku diet vegetarian di Indonesia yang tercatat sebagai anggota Indonesian Vegetarian Society (IVS) diprediksi mencapai angka 500.000 anggota pada tahun 2010 (Fikawati, 2012). Vegetarian merupakan pola makan yang hanya mengonsumsi pangan nabati kecuali pada ovo vegetarian yang masih mengonsumsi telur dan produk olahannya (Rahmi, 2015). Perkembangan vegetarian semakin lama tidak hanya didasarkan pada ajaran agama saja, namun berbagai motivasi lain juga dapat membuat seseorang menganut pola makan vegetarian (Yuliarti, 2008). Pola makan vegetarian berisiko untuk mengalami defisiensi zat gizi tertentu karena terbatasnya asupan makanan yang dikonsumsi. Dalam suatu penelitian dinyatakan bahwa asupan zat besi pada 39,29\% vegetarian kurang, begitu juga dengan asupan vitamin B12 pada vegetarian sebesar 92,86\% masih kurang (Jannah, 2011). Zat besi yang terkandung dalam sumber nabati adalah zat besi non-heme yang proses penyerapannya tergantung pada faktor-faktor luar, sedangkan sumber vitamin B12 sebagian besar berasal dari sumber makanan hewani (Anggraini, 2015). Defisiensi zat besi dan vitamin B12 pada pola makan ovo vegetarian dapat berpengaruh pada kejadian anemia. Kejadian anemia pada Wanita Usia Subur (WUS) mencapai 26,9\% (Kemenkes, 2013). Suatu penelitian menunjukkan kejadian anemia pada WUS vegetarian mencapai 56,5\% (Nugroho, 2015). Kelompok ini berisiko karena pola makan pada WUS vegetarian hanya didominasi oleh sumber nabati (Agtrin, 2016).

Upaya yang dapat dilakukan untuk mencegah kejadian anemia pada WUS dengan pola makan ovo vegetarian adalah melalui inovasi suatu produk makanan. Brownies ialah salah satu jenis cake yang berwarna cokelat kehitaman dengan tekstur sedikit lebih keras dari pada cake pada umumnya (Astawan, 2009). Brownies merupakan salah satu kue dengan daya terima baik dan digemari oleh sebagian besar masyarakat (Windayarti, 2013). Bahan dasar pembuatan brownies antara lain tepung terigu, gula, margarin, telur, cokelat batang, cokelat bubuk, baking powder, dan garam (Sutomo, 2012). Sebagai alternatif pemenuhan keanekaragaman dalam mencegah defisiensi zat besi dan vitamin B12 pada ovo vegetarian dapat dilakukan pemberian makanan dengan bahan substitusi sumber zat besi dan vitamin B12 seperti tepung kedelai, tepung bekatul dan tepung rumput laut (Gracilaria sp).

Kedelai merupakan komoditas pangan penghasil protein nabati yang sangat penting. Selain banyak mengandung protein, kedelai juga mengandung mineral dan vitamin yang cukup tinggi, diantaranya adalah vitamin B1, B2, B3, B12, dan vitamin E. Kedelai juga mengandung beberapa mineral berupa kalsium, zat besi, dan fosfor (Sarwono, 2010). Kandungan zat besi dalam kedelai mencapai $16 \mathrm{mg} / 100 \mathrm{~g}$ kedelai (Winarsi, 2010). Saat ini pemanfaatan kedelai lebih banyak pada pembuatan tempe, kacang, tauco, dan tahu (Koswara, 2009).

Bekatul adalah lapisan sebelah dalam butiran padi yang merupakan hasil limbah dari penggilingan padi yang terdiri dari lapisan kulit ari dan sebagian kecil endosperm berpati (Astawan, 2009). Bekatul memiliki potensi untuk dikembangkan sebagai pangan fungsional karena berkorelasi positif dengan padi yang menjadi konsumsi utama masyarakat di Indonesia, namun pemanfaatan bekatul sebagai makanan saat ini masih terbatas padahal bekatul memiliki kandungan gizi yang cukup tinggi yaitu 18,5 mg zat besi per 100 gram bekatul (Ide, 2010).

Rumput laut (Gracilaria sp) merupakan salah satu jenis rumput laut yang mudah diperoleh dan memiliki beberapa komponen penting seperti protein, lemak, dan vitamin B12 (Anggadiredja, 2006). Salah satu penelitian menunjukkan, terdapat 3,05 $\mu \mathrm{g}$ vitamin B12 dalam 100 gram tepung rumput laut Gracilaria sp (Febriyanti, 2011).

Berdasarkan pernyataan diatas, perlu dilakukan penelitian guna mengetahui pengaruh tepung kedelai, tepung bekatul dan tepung rumput laut (Gracilaria sp) sebagai bahan substitusi brownies agar dapat diterima di masyarakat khususnya penganut pola makan ovo vegetarian yang dilihat dari segi daya terima serta peningkatan 
zat besi dan vitamin B12 sebagai snack alternatif untuk ovo vegetarian.

\section{METODE}

Penelitian ini merupakan eksperimental murni (True Experimental Research) dengan rancang bangun penelitian Rancang Acak Lengkap (RAL) pada formula brownies substitusi tepung kedelai, tepung bekatul dan tepung rumput laut (Gracilaria $s p$ ) dengan pengulangan sebanyak 6 kali pada setiap formula. Penelitian ini berlangsung selama 4 bulan diawali pada bulan Maret hingga bulan Juni 2017. Dilakukan penelitian pengembangan produk brownies dan juga uji laboratorium nilai zat besi dan vitamin B12 yang dilakukan di Laboratorium Fakultas Kesehatan Masyarakat Universitas Airlangga Surabaya, selanjutnya penelitian daya terima pada panelis tidak terlatih dilakukan di Vihara Buddhayana Surabaya.

Sampel yang digunakan untuk mengetahui daya terima panelis disajikan sebesar 25 gram pada masing-masing formula brownies, sedangkan pada formula yang akan dilakukan pengujian nilai zat besi dan vitamin B12 yaitu sebesar 100 gram formula yang terpilih. Metode pengambilan sampel dilakukan secara acak sehingga seluruh sampel yang disajikan mendapatkan peluang yang sama pada setiap perlakuan.

Panelis tidak terlatih yang terlibat adalah penganut pola makan ovo vegetarian di Vihara Buddhayana Surabaya yaitu sebanyak 25 orang yang akan memberikan penilaian kepada beberapa formula brownies terpilih. Penilaian daya terima yang dilakukan meliputi warna, aroma, tekstur, dan rasa brownies dengan menggunakan angket uji hedonik dengan 3 skala yaitu suka, agak suka dan tidak suka. Bahan yang digunakan dalam pembuatan produk brownies ini antara lain tepung terigu, tepung kedelai, tepung bekatul, tepung rumput laut (Gracilaria $s p$ ), gula pasir, cokelat blok, cokelat bubuk, margarin, telur, garam, dan baking powder seperti yang presentase ditampilkan pada tabel 1. Presentase substitusi tepung kedelai, tepung bekatul dan tepung rumput laut (Gracialria $s p$ ) yang digunakan pada pembuatan brownies disesuaikan dengan kebutuhan wanita usia subur dan batas penggunaan bahan tersebut pada pembuatan kue.

Tahap pertama pembuatan brownies yaitu dimulai dengan mempersiapkan alat dan bahan yang akan digunakan selama proses pengolahan brownies, semua bahan-bahan yang digunakan ditimbang dengan menggunakan timbangan digital sesuai dengan berat setiap formula yang telah ditentukan. Panaskan margarin, kemudian masukkan potongan cokelat batang dan gula pasir sambil diaduk-aduk hingga margarin dan cokelat meleleh serta gula larut. Siapkan wadah lain, campurkan tepung, cokelat bubuk, baking powder, dan garam halus kemudian aduk rata sebelum disisihkan. Kocok telur di tempat terpisah dengan menggunakan mixer selama 5 menit hingga mengental. Masukkan tepung terigu dan tambahkan tepung kedelai, tepung bekatul, dan tepung rumput laut untuk brownies (F1, F2, F3) ke dalam cokelat tim, aduk dengan menggunakan mixer dengan kecepatan rendah, masukkan kocokan telur lalu aduk hingga rata. Tuang adonan brownies ke dalam loyang yang sebelumnya telah diberi alas kertas roti yang diberi olesan margarin. Panggang adonan brownies di dalam oven dengan temperatur $170^{\circ} \mathrm{C}$ selama 40 menit atau hingga brownies matang, lalu angkat dan dinginkan.

Teknik pengumpulan data pada penelitian ini dilakukan dengan penilaian daya terima oleh panelis yang meliputi karakteristik warna, aroma, tekstur, dan rasa menggunakan angket uji organleptik dan melakukan perhitungan nilai zat besi dan vitamin B12 berdasarkan Nutrisurvey.

Setelah dilakukan penilaian terhadap daya terima panelis pada seluruh formula brownies, data yang didapatkan akan diolah untuk menentukan formula brownies dengan nilai daya terima tertinggi. Teknik analisis statistik pada penilaian daya terima menggunakan uji Friedman Test. Selanjutnya, dilakukan uji analisis zat besi dan vitamin $\mathrm{B} 12$ pada brownies dengan penilaian daya terima tertinggi.

Penelitian ini telah lulus uji etik oleh komite etik dan telah mendapatkan persetujuan, hal tersebut dibuktikan dengan adanya sertifikat etik No.: 242-KEPK Fakultas Kesehatan Masyarakat Universitas Airlangga. Uji etik dilakukan pada 
penelitian ini karena melibatkan subyek manusia yang menjadi panelis dalam penilaian daya terima brownies.

\section{HASIL DAN PEMBAHASAN}

Brownies merupakan kue cokelat yang memiliki rasa manis, warna menarik, aroma yang lezat, serta tekstur yang tidak terlalu mengembang (Windyarti, 2013). Melalui Uji daya terima yang dilakukan pada panelis tidak terlatih sebanyak 25 orang penganut pola makan ovo vegetarian di Vihara. Buddhayana Surabaya terhadap tingkat kesukaan warna, aroma, tekstur tidak menunjukkan adanya perbedaan. Namun, pada karakteristik rasa memperlihatkan adanya perbedaan.

Perbedaan terjadi karena perlakuan pada setiap formula brownies memiliki persentase yang berbeda pada tepung terigu, tepung kedelai, tepung bekatul, dan tepung rumput laut sehingga dapat memengaruhi rasa brownies. Hasil uji daya terima warna akan disajikan pada tabel 2.

Tabel 1. Formulasi Brownies Dasar dan Brownies Substitusi

\begin{tabular}{|c|c|c|c|c|}
\hline \multirow{2}{*}{ Komposisi } & \multicolumn{4}{|c|}{ Formula (g) } \\
\hline & F0 & F1 & F2 & F3 \\
\hline \multicolumn{5}{|l|}{ Bahan Utama } \\
\hline Tepung terigu & 150 & 45 & 37,5 & 37,5 \\
\hline Tepung kedelai ${ }^{1}$ & 0 & 30 & 75 & 22,5 \\
\hline Tepung bekatul ${ }^{2}$ & 0 & 30 & 15 & 75 \\
\hline Tepung rumput laut ${ }^{3}$ & 0 & 45 & 22,5 & 15 \\
\hline \multicolumn{5}{|l|}{ Bahan Tambahan } \\
\hline Gula pasir & 150 & 150 & 150 & 150 \\
\hline Cokelat bubuk & 40 & 40 & 40 & 40 \\
\hline Cokelat blok & 200 & 200 & 200 & 200 \\
\hline Baking powder & 2 & 2 & 2 & 2 \\
\hline Margarin & 200 & 200 & 200 & 200 \\
\hline Telur & 150 & 150 & 150 & 150 \\
\hline Garam & 2 & 2 & 2 & 2 \\
\hline
\end{tabular}

Keterangan:

F0 : tepung terigu $150 \mathrm{~g}$, tepung kedelai $0 \mathrm{~g}$, tepung bekatul $0 \mathrm{~g}$, tepung rumput laut $0 \mathrm{~g}$

F1 : tepung terigu $45 \mathrm{~g}$, tepung kedeli $30 \mathrm{~g}$, tepung bekatul $30 \mathrm{~g}$, tepung rumput laut $45 \mathrm{~g}$

F2 : tepung terigu $37,5 \mathrm{~g}$, tepung kedelai $75 \mathrm{~g}$, tepung bekatul $15 \mathrm{~g}$, tepung rumput laut $22,5 \mathrm{~g}$

F3 : tepung terigu $37,5 \mathrm{~g}$, tepung kedelai $22,5 \mathrm{~g}$, tepung brkatul $75 \mathrm{~g}$, tepung rumput laut $15 \mathrm{~g}$

1 (Noviyanti, 2017), 2 (Kusumastuty, 2015), 3 (Handayani, 2011)
Tabel 2 memperlihatkan sebagian besar panelis menyatakan suka pada brownies dengan formula kontrol maupun formula substitusi (F3) sebagian kecil diantaranya menyatakan agak suka dan tidak suka pada brownies kontrol dan brownies substitusi (F1 dan F2). Hasil rata-rata tertinggi terdapat pada formula F3 dengan nilai rata-rata 2,76 dan terendah yaitu formula F2 dengan nilai rata-rata 2,52. Tidak ada perbedaan yang mencolok pada formula brownies kontrol dan substitusi karena bahan substitusi yang digunakan tidak memengaruhi warna khas brownies. Warna brownies kontrol dan substitusi adalah cokelat kehitaman. Brownies adalah salah satu jenis cake yang berwarna cokelat kehitaman (Astawan, 2009).

Aroma merupakan sesuatu yang dirasakan oleh indera penciuman dan merupakan salah satu parameter dalam menentukan rasa enak dari suatu produk makanan (Winarno, 2004). Distribusi tingkat kesukaan panelis terhadap aroma brownies akan ditampilkan pada tabel 2. Sebagian panelis menyatakan suka dan agak suka pada brownies kontrol maupun brownies substitusi (F3) dan sebagian kecil menyatakan tidak suka pada formula kontrol dan formula substitusi (F1 dan F2). Perolehan tertinggi pada F3 dengan nilai ratarata 2,6 dan terendah pada F2 dengan nilai rata-rata 2,3. Panelis kurang menyukai aroma langu yang terjadi akibat penambahan bahan substitusi tepung kedelai dengan takaran tertinggi pada F2.

Tepung kedelai mengandung zat off flavor yang dapat menimbulkan aroma langu yang disebabkan oleh adanya enzim lipoksidase pada kedelai (Santoso, 2009). Aroma langu tersebut dapat diatasi dengan melakukan penyangraian pada tepung kedelai.

Tekstur merupakan penilaian penting untuk menilai mutu dari suatu produk makanan. Cake terdiri dari beberapa variasi, yaitu spikuk, roll tart, muffin, brownies, dan tart cake (Miranti, 2008). Brownies adalah salah satu jenis cake yang memiliki tekstur lebih keras apabila dibandingkan dengan cake lainnya (Astawan, 2009). Hal ini karena dalam pembuatannya, brownies tidak membutuhkan banyak pengembang. Distribusi tingkat kesukaan panelis terhadap tekstur brownies akan ditampilkan pada tabel 2 . 
Tabel 2. Distribusi Tingkat Kesukaan Panelis terhadap Brownies

\begin{tabular}{|c|c|c|c|c|c|c|c|c|c|c|}
\hline \multirow{2}{*}{ Formula } & \multicolumn{2}{|c|}{ Tidak suka } & \multicolumn{2}{|c|}{ Agak suka } & \multicolumn{2}{|c|}{ Suka } & \multicolumn{2}{|c|}{ Total } & \multirow{2}{*}{ Mean Ranks } & \multirow{2}{*}{ p-value } \\
\hline & $\mathbf{n}$ & $\%$ & $\mathbf{n}$ & $\%$ & $\mathbf{n}$ & $\%$ & $\mathbf{n}$ & $\%$ & & \\
\hline \multicolumn{11}{|l|}{ Warna } \\
\hline F0 & 1 & 4 & 5 & 20 & 19 & 76 & 25 & 100 & 2,72 & \multirow{4}{*}{0,290} \\
\hline $\mathrm{F} 1$ & 1 & 4 & 8 & 32 & 16 & 64 & 25 & 100 & 2,6 & \\
\hline F2 & 2 & 8 & 8 & 32 & 15 & 60 & 25 & 100 & 2,52 & \\
\hline F3 & 0 & 0 & 6 & 24 & 19 & 76 & 25 & 100 & 2,76 & \\
\hline \multicolumn{11}{|l|}{ Aroma } \\
\hline F0 & 2 & 8 & 8 & 32 & 15 & 60 & 25 & 100 & 2,5 & \multirow{4}{*}{0,404} \\
\hline F1 & 4 & 16 & 7 & 28 & 14 & 56 & 25 & 100 & 2,4 & \\
\hline F2 & 4 & 16 & 10 & 40 & 11 & 44 & 25 & 100 & 2,3 & \\
\hline F3 & 0 & 0 & 10 & 40 & 15 & 60 & 25 & 100 & 2,6 & \\
\hline \multicolumn{11}{|l|}{ Tekstur } \\
\hline F0 & 2 & 8 & 7 & 28 & 16 & 64 & 25 & 100 & 2,56 & \multirow{4}{*}{0,360} \\
\hline $\mathrm{F} 1$ & 6 & 24 & 8 & 32 & 11 & 44 & 25 & 100 & 2,2 & \\
\hline F2 & 3 & 12 & 9 & 36 & 13 & 52 & 25 & 100 & 2,4 & \\
\hline F3 & 2 & 8 & 12 & 48 & 11 & 44 & 25 & 100 & 2,36 & \\
\hline \multicolumn{11}{|l|}{ Rasa } \\
\hline F0 & 0 & 0 & 6 & 24 & 19 & 76 & 25 & 100 & 2,76 & \multirow{4}{*}{0,005} \\
\hline $\mathrm{F} 1$ & 7 & 28 & 9 & 36 & 9 & 36 & 25 & 100 & 2,08 & \\
\hline F2 & 6 & 24 & 7 & 28 & 12 & 48 & 25 & 100 & 2,24 & \\
\hline F3 & 7 & 28 & 6 & 24 & 12 & 48 & 25 & 100 & 2,2 & \\
\hline
\end{tabular}

Sebagian besar panelis menyatakan suka pada brownies kontrol serta brownies substitusi (F2) dan sebagian panelis menyatakan agak suka pada formula substitusi (F3) serta tidak suka pada formula substitusi (F1). Penilaian tertinggi pada F0 dengan nilai rata-rata 2,56 dan terendah pada $\mathrm{F} 1$ dengan nilai rata-rata 2,2. F1 merupakan brownies dengan substitusi tertinggi pada tepung rumput laut (Gracilaria sp). Tepung rumput laut yang bersifat karaginan dapat menghasilkan produk yang lebih basah dalam pembuatan kue (Handayani, 2011). Tekstur brownies yang lebih basah kurang disukai oleh panelis.

Rasa merupakan penilaian suatu produk dengan melibatkan lidah yang dikenal oleh kucupkucup lidah dan terbagi menjadi rasa manis, asam, pahit, dan asin (Winarno, 2004). Brownies adalah kue cokelat dengan rasa yang manis (Windayarti, 2013). Distribusi tingkat kesukaan panelis terhadap karakteristik rasa akan ditampilkan pada tabel 2.

Tabel 2 memperlihatkan distribusi tingkat kesukaan panelis terhadap rasa brownies. Sebagian besar panelis menyatakan suka dengan brownies kontrol dan brownies substitusi (F2 dan F3). Nilai rata-rata tertinggi pada F0 dengan nilai 2,76 dan terendah pada F1 dengan nilai 2,08. Panelis menyukai rasa manis yang merupakan ciri khas dari brownies.

Formula dengan penggunaan tepung rumput laut tertinggi akan mengurangi rasa manis dari brownies. Penggunaan tepung rumput laut pada pembuatan suatu produk kue dapat menyebabkan berkurangnya rasa manis pada produk kue tersebut (Handayani, 2011). Hal ini karena rumput laut memiliki sifat karaginan yang bersifat sebagai pengental sehingga dapat mengurangi rasa manis pada suatu produk (Violisa, 2012).

Hasil uji daya terima brownies secara keseluruhan ditampilkan pada gambar 1. Hasil uji daya terima brownies menunjukkan perbedaan yang tidak signifikan pada karakteristik warna, aroma dan tekstur dengan hasil uji statistik Friedman Test $\alpha \geq 0,05$ sedangkan hasil signifikan didapatkan pada karakteristik rasa dengan hasil $\alpha$ $\leq 0,05$ pada formula $\mathrm{F} 0$ dengan $\mathrm{F} 1, \mathrm{~F} 0$ dengan F2 dan F0 dengan F3. Formula substitusi brownies yang memiliki daya terima tertinggi adalah F3 dengan komposisi tepung terigu sebanyak 37,5 gram, tepung kedelai 22,5 gram, tepung bekatul 75 gram dan tepung rumput laut (Gracilaria $s p$ ) sebanyak 15 gram. 
Penilaian daya terima yang dilakukan oleh panelis adalah penilaian uji organoleptik atau yang disebut juga dengan uji inderawi yang digunakan selain pada industri hasil pertanian juga banyak digunakan dalam penilaian mutu industri pangan (Susiwi, 2009). Penilaian sifat inderawi suatu produk makanan yaitu meliputi indera penglihatan yang berhubungan dengan warna, indera penciuman yang berhubungan dengan aroma, indera peraba yang berhubungan dengan tekstur, dan indera pengecap yang berhubungan dengan rasa. Berdasarkan gambar 1 dapat disimpulkan bahwa formula substitusi yang memiliki karakteristik hampir sama dengan formula kontrol (F0) adalah formula substitusi F3, dapat diketahui bahwa formula substitusi yang mendapat daya terima baik oleh panelis adalah formula F3. Selain penilaian daya terima brownies, penilaian kecukupan zat besi dan vitamin B12 untuk WUS ovo vegetarian juga perlu diperhatikan.

Kebutuhan zat besi dan vitamin B12 WUS ovo vegetarian yang harus dipenuhi adalah $2,6-3,9$ $\mathrm{mg}$ zat besi dan $0,24-0,36 \mu \mathrm{g}$ vitamin B12 untuk 10-15\% kebutuhan snack. Angka tersebut sesuai dengan AKG Wanita Usia Subur dengan rentan usia 19-29 tahun. Brownies substitusi tepung kedelai, tepung bekatul dan tepung rumput laut (Gracilaria sp) merupakan snack dengan sumber zat besi dan vitamin B12. Perhitungan dengan menggunakan Nutrisurvey akan ditampilkan pada tabel 3.

Tabel 3 menunjukkan perbandingan kandungan zat besi dan vitamin B12 per 100 gram brownies menggunakan perhitungan DKBM dan hasil uji laboratorium. Nilai zat besi yang ditunjukkan pada tabel tersebut menunjukkan bahwa brownies dengan kandungan zat besi tertinggi adalah

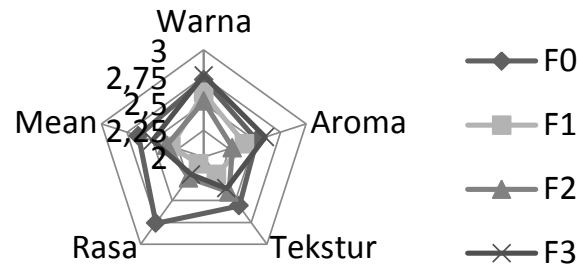

Gambar 1. Grafik Radar Daya Terima Brownies

formula substitusi F3 dan untuk kandungan vitamin B12 menurut DKBM didapatkan hasil tertinggi pada formula substitusi F1. Berdasarkan hasil tersebut dapat diketahui bahwa 100 gram brownies dapat memenuhi kebutuhan zat besi dan vitamin B12 snack sesuai dengan AKG Wanita Usia Subur sebanyak 10-15\% kebutuhan zat besi dan vitamin B12 setiap harinya yaitu 2,6 mg zat besi dan $0,24 \mu \mathrm{g}$ vitamin B12. Hasil uji laboratorium menunjukkan adanya penurunan pada kandungan zat besi. Penurunan kandungan zat besi dalam brownies disebabkan karena pengolahan atau proses pemasakan yang dilakukan. Penurunan kandungan mineral seperti zat besi akibat proses pemasakan seperti pemaparan bahan makanan pada panas yang tinggi dapat mengurangi kandungannya hingga mencapai 5-40\% (Sundari, 2015). Sementara pada pemeriksaan laboratorium vitamin B12 mengalami peningkatan. Peningkatan ini terjadi karena perhitungan dengan uji laboratorium lebih teliti. Perhitungan nilai gizi dengan DKBM menggunakan kandungan gizi yang telah ditetapkan sebelumnya sehingga memungkinkan terjadinya perubahan antara perhitungan DKBM dengan perhitungan laboratorium.

\section{KESIMPULAN DAN SARAN}

Produk brownies substitusi tepung kedelai, tepung bekatul dan tepung rumput laut (Gracilaria

Tabel 3. Distribusi Kandungan Zat Besi dan Vitamin B12 per 100 gram Brownies

\begin{tabular}{ccccc}
\hline \multirow{2}{*}{ Formula } & \multicolumn{2}{c}{ Kandungan Zat Besi $(\boldsymbol{\mu g})$} & \multicolumn{2}{c}{ Kandungan Vitamin B12 $(\mathbf{m g})$} \\
\cline { 2 - 5 } & Perhitungan DKBM & Uji Laboratorium & Perhitungan DKBM & Uji Laboraturium \\
\hline F0 & 1,6 & - & 0,19 & - \\
F1 & 3 & - & 0,3 & - \\
F2 & 3,3 & - & 0,3 & 1,867 \\
F3 & 3,6 & 0,00397 & 0,23 & - \\
\hline
\end{tabular}

(-): tidak dilakukan analisis laboratorium 
sp) mendapatkan daya terima yang baik oleh panelis setelah melalui penilaian uji organoleptik berdasarkan karakteristik warna, aroma, tekstur, dan rasa. Formula substitusi terpilih yang merupakan formula dengan daya terima tertinggi adalah formula substitusi F3 (22,5 gram tepung kedelai, 75 gram tepung bekatul dan 15 gram tepung rumput laut (Gracilaria $s p$ )), formula F3 memiliki penilaian warna, aroma, tekstur, dan rasa tertinggi dibandingkan dengan formula substitusi lainnya. Formula substitusi F3 telah memenuhi 10$15 \%$ kandungan zat besi dan vitamin B12 sesuai AKG Wanita Usia Subur (WUS) melalui konsumsi 100 gram brownies, sehingga layak untuk dijadikan sebagai snack alternatif dengan kandungan zat besi dan vitamin B12 untuk WUS dengan pola makan ovo vegetarian.

Penelitian selanjutnya baiknya memperhatikan pengolahan brownies yang memungkinkan terpapar panas agar tidak mengurangi kandungan zat besi terlalu banyak. Proses penyangraian pada tepung kedelai dan bekatul untuk menghilangkan bau langu juga perlu dilakukan sehingga tidak memengaruhi aroma brownies.

\section{DAFTAR PUSTAKA}

Agtrin, M.W. (2016). Hubungan antara asupan protein dan zat besi dengan kadar hemoglobin pada wanita vegetarian usia 20-45 tahun di vihara semesta maitreya kota Semarang.

Anggadiredja. (2006). Rumput laut. Jakarta: Dian Rakyat.

Anggraini, L. (2015). Asupan gizi dan status gizi vegetarian pada komunitas vegetarian di yogyakarta. Jurnal Gizi Klinik Indonesia 11(4), 143-149.

Astawan, M. (2009). Sehat dengan hidangan kacang dan biji-bijian. Jakarta: Dian Rakyat.

Fikawati, S. (2012). Status gizi ibu hamil dan berat bayi pada kelompok vegetarian. Jurnal Makara Kesehatan. Diakses dari journal.ui.ac.id/index. php/health/article/viewFile/1299/1188.

Handayani. (2011). Variasi rumput laut terhadap kadar serat dan mutu organoleptik cake rumput laut (euchema cottonii). Jurnal Pangan dan Gizi 2(3). Diakses dari http://download.portalgaruda. org $/$ article.php? article $=161555 \& \mathrm{val}=425 \& \mathrm{t}$ itle $=$ Variasi $\% 20$ Substitusi $\% 20$ Rumput $\% 20$ Laut\%20Terhadap\%20Kadar\%20Serat $\% 20$
Dan\%20Mutu\%20Organoleptik\%20Cake\%20 Rumput\%20Laut.

Ide, P. (2010). Agar jantung sehat: tip dan trik memilih makanan agar jantung sehat. Jakarta: PT. Elex Media Komputindo.

Jannah, M. (2011). Perbedaan asupan zat Gizi dan non gizi yang berkaitan dengan kadar hemoglobin vegetarian vegan dan non vegan. Skripsi. Universitas Diponegoro. Semarang. Diakses dari eprints.undip.ac.id/32607/1/404_ MIFTAHUL_JANNAH_G2C007046.pdf

Kementerian Kesehatan Republik Indonesia. (2013). Riset kesehatan dasar. Jakarta: Badan Penelitian dan Pengembangan Kesehatan.

Koswara, S. (2009). Teknologi pengolahan kedelai (teori dan praktek). Universitas Muhammadiyah Semarang. Diakses dari http://tekpan.unimus. ac.id/wpcontent/uploads/2013/07/TeknologiPengolahan-Kedelai-Teori-dan-Praktek.pdf.

Kusumastuty, I. (2015). Formulasi food bar tepung bekatul dan tepung jagung sebagai Pangan darurat. Indonesian journal of human nutrition 2(2). Diakses dari http://download.portalgaruda. org/article.php?article $=371544 \&$ val $=7364 \&$ titl e=Formulasi\%20Food\%20Bar\%20Tepung\%20 Bekatul\%20dan\%20Tepung\%20Jagung\%20 sebagai\%20Pangan\%20Darurat.

Miranti. (2008). Pengembangan usaha "elsari brownies and bakery" analisis aspek pasar dan keuangan. Bogor.

Noviyanti, R. (2017). Analisis kadar gula, kadar protein dan organoleptik bolu kukus substitusi tepung kedelai (Glicine L. Merr). The $5^{\text {th }}$ Urecol Proceeding 1066. Diakses dari http:// lpp.uad.ac.id/wp-content/uploads/2017/05/186RETNO-1066-1073.pdf.

Nugroho, F. (2015). Asupan protein nabati dan kejadian anemia wanita usia subur vegan. J. Gizi Pangan 10 (3). Diakses dari http://download. portalgaruda.org/article.php? article $=419213 \&$ val=199\& title $=$ ASUPAN $\% 20$ PROTEIN $\% 20$ NABATI\%20DAN\%20KEJADIAN\%20 ANEMIA $\% 20$ WANITA $\% 20$ USIA $\% 20$ SUBUR\%20VEGAN.

Rahmi, R. (2015). Kecukupan asupan protein dan asupan vitamin B12 pada anak vegetarian di sekolah dasar metta maitreya. JOM FK 2(2).

Rokhmani, I. (2009). Peningkatan nilai gizi bahan pakan dari limbah pertanian melalui fermentasi. balai pertanian ternak Bogor. Diakses dari http://peternakan.litbang.pertanian.go.id/ fullteks/lokakarya/lklc05-10.pdf?secure=1. 
Santoso, S.P. (2009). Susu dan yoghurt kedelai. Malang: Laboratorium Kimia Pangan Faperta UWG.

Sarwono. (2010). Usaha membuat tempe dan oncom. Jakarta: Penebar Swadaya.

Sundari. (2015). Pengaruh proses pemasakan terhadap komposisi zat gizi bahan pangan sumber protein. Media Litbangkes 25(4). Diakses dari https://media.neliti.com/media/ publications/20747-ID-pengaruh-prosespemasakan-terhadap-komposisi-zat-gizi-bahanpangan-sumber-protei.pdf.

Susiwi. (2009). Penilaian organoleptik. Bogor: Universitas Pendidikan Indonesia.

Sutomo, B. (2012). Rahasia sukses membuat cake, roti, kue kering, dan jajan pasar. Jakarta: Ns Books.
Violisa, A. (2012). Penggunaan rumput laut sebagai stabilizer es krim susu sari kedelai. Teknologi dan Kejuruan 35(1). Diakses dari http://journal. um.ac.id/index.php/teknologi-kejuruan/article/ viewFile/3711/645.

Winarno. (2004). Kimia pangan dan gizi. Jakarta: PT. Gramedia Pustaka Utama.

Winarsi, H. (2010). Protein kedelai dan kecambah manfaat bagi kesehatan. Jakarta: PT. Gramedia Pustaka Utama.

Windayarti, T. (2013). Karakteristik brownies yang dibuat dari komposisi tepung gembolo (discorea bulbifer L). Jurnal Berkala Universitas Negeri Jember 1(2). Diakses dari http://jurnal.unej. ac.id/index.php/index/index. 